Urszula Kluczyńska

Collegium da Vinci, Poznań

\title{
Socjologiczne studia nad mężczyznami i męskościami w Polsce. Obszary, perspektywy, teorie
}

\begin{abstract}
Sociological Studies on Men and Masculinities in Poland: Areas, Perspectives and Theories
\end{abstract}

A review of the sociological research on men and masculinities in Poland, its development and the evaluation are the main aims of this article. The author describes the development in Western and Polish studies on men and masculinities, and focuses on differences between them and consequences thereof the Polish academy. Areas of research and theories applied in Polish sociological studies on men and masculinities are also described.

Słowa kluczowe: men’s studies, krytyczne studia nad mężczyznami i męskościami, socjologia męskości, mężczyźni

Keywords: men's studies, critical studies on men and masculinities, sociology of men and masculinities, men 


\section{Wprowadzenie - początki studiów nad mężczyznami i męskościa- mi na świecie}

Początki socjologicznych analiz męskości w Stanach Zjednoczonych sięgają lat pięćdziesiątych XX wieku. Jednak ich rozwój ${ }^{1}$ - głównie w USA i Europie Zachodniej - można datować na lata siedemdziesiąte, kiedy to rozpoczęto dyskusje nad męskością w wyniku działań ruchu kobiet i refleksji drugiej fali feminizmu.

Pierwsza fala studiów męskich koncentrowała się wokół krytyki ról płciowych, problematyki męskiej roli oraz jej kosztów. Deborah S. David i Robert Brannon $^{2}$ opisywali męską rolę przez cztery reguły: no sissy staff, be a big wheel, be a sturdy oak, give'em hell. Męska rola łączona była zatem z dystansowaniem się wobec kobiecości, brakiem emocjonalności, przypisywanej wyłącznie kobietom, a także z przymusem odniesienia sukcesu, rywalizacją i dążeniem do kontroli rzeczywistości oraz sankcjonowaniem agresji. Krytykę teorii ról płciowych podjęli Joseph H. Pleck ${ }^{3}$ oraz Tim Carrigan, Bob Connell i John $\mathrm{Lee}^{4}$, którzy podkreślali, że męska rola to daleko idące uproszczenie, albowiem niemożliwe jest wyizolowanie roli, która konstruuje męskość. $\mathrm{Na}$ drugi - datowany na lata osiemdziesiąte - etap rozwoju studiów męskich, miały wpływ dwa podejścia, które w sposób istotny zróżnicowały zachodnie men's studies. Wyłonił się nurt profeministyczny, oparty na założeniach trzeciej fali feminizmu i przyjmujący perspektywę konstruktywistyczną. Wówczas skoncentrowano się na analizie sytuacji mężczyzn jako ojców oraz zjawisku męskiej dominacji, podważaniu heteroseksizmu, ukazywaniu nierówności związanych z płcią ${ }^{5}$ Z kolei drugi nurt tego etapu związany był ze zjawiskiem

${ }^{1}$ Początki studiów nad mężczyznami i męskościami w zachodniej literaturze zaledwie sygnalizuję, szerzej na ten temat w: S.M. Whitehead, F.J. Barrett, The Sociology of Masculinity [w:] The Masculinities Reader, eds. S.M. Whitehead, F.J. Barrett, Cambridge 2001, ale także w polskiej literaturze, m.in.: U. Kluczyńska, Mężczyźni w pielęgniarstwie. W stronę męskości opiekuńczej, Poznań 2017, s. 12-14; U. Kluczyńska, K. Wojnicka, Wymiary męskości, „InterAlia” 2015, nr 10, s. 1-6; K. Wojnicka, E. Ciaputa, Wprowadzenie: refleksja naukowa nad społeczno-kulturowymi fenomenami męskości [w:] Karuzela z mężczyznami. Problematyka męskości w polskich badaniach spotecznych, red. K. Wojnicka, E. Ciaputa, Kraków 2011, s. 7-21; B. Kwaśny, Polskie studia nad męskościa, „Zeszyty Etnologii Wrocławskiej” 2009, nr 1 (11), s. 7-27; K. Arcimowicz, Obraz mężczyzny w polskich mediach. Prawda-fatsz - stereotyp, Gdańsk 2003, s. 58-62.

2 The Forty-Nine Percent Majority: The Male Sex, eds. D.S. David, R. Brannon, Reading 1976.

3 J.H. Pleck, The Myth of Masculinity, London 1981.

${ }^{4}$ T. Carrigan, B. Connell, J. Lee, Toward a New Sociology of Masculinity [w:] The Making of Masculinities: The New Men's Studies, ed. H. Brod, Boston 1987.

5 S.M. Whitehead, F.J. Barrett, op.cit., s. 15. 
określonym mianem backlash ${ }^{6}$, czyli ideą odwrotu od feminizmu i przekonaniem, że zaszedł on za daleko i szkodzi kobietom ${ }^{7}$. Przyjęto tu esencjalistyczną perspektywę do opisu płci, odwoływano się do „naturalnych” różnic płciowych i wartości tradycyjnej męskości ${ }^{8}$.

Kluczowym konceptem w opisie relacji władzy między kobietami a mężczyznami, ale również między mężczyznami, stała się teoria męskości hegemonicznej R.W. Connell9. Kolejny etap rozwoju studiów nad mężczyznami i męskościami był bowiem związany z wpływem feministycznego poststrukturalizmu i teorii postmodernistycznych, a co za tym idzie - z krytyką dominującej dotąd perspektywy badawczej. Analizowano zatem przede wszystkim sposób, w jaki tożsamość mężczyzn jest uprawomocniana przez dominujące dyskursywne praktyki oraz w jaki sposób ta praca tożsamościowa łączy się z władzą i oporem w kontekście genderowym, jak dochodzi do konstruowania i negocjowania podmiotu $\mathrm{w}$ dyskursie ${ }^{10}$. Zmiana sposobu myślenia o męskościach wiąże się zatem z odejściem od analiz z perspektywy hierarchicznej na rzecz męskości alternatywnych funkcjonujących w horyzontalnym porządku. Przykładem tego podejścia są badania męskości inkluzywnej Erica Andersona $^{11}$ czy badania nad męskością opiekuńczą ${ }^{12}$.

Pionierzy men's studies (m.in. Harry Brod ${ }^{13}$ ) uważali się za kontynuatorów myśli feministycznej, a celem ich badań było pogłębienie analiz nad specyfiką męskich doświadczeń zanurzonych w społeczno-kulturowych i historycznych kontekstach. Studia męskie miały się stać uzupełnieniem studiów kobiecych i podjąć pytania o doświadczenie codziennego życia mężczyzn ${ }^{14}$. Ich celem nie było jednak ani pisanie historii, która byłaby historią mężczyzn

${ }^{6}$ S. Faludi, Reakcja. Niewypowiedziana wojna przeciw kobietom, przeł. A. Dzierzgowska, wstęp A. Graff, Warszawa 2013.

${ }^{7}$ Szerzej zob. rozdział Męskość jako kategoria teoretyczna, analityczna i społeczna [w:] U. Kluczyńska, Metamorfozy tożsamości współczesnych młodych mężczyzn, Torun 2009.

${ }_{8}^{8}$ R. Bly, Żelazny Jan. Rzecz o mężczyznach, przeł. J. Tittenbrun, Poznań 2004.

${ }^{9}$ R. W. Connell, Masculinities, Berkeley-Los Angeles 1995.

${ }^{10}$ S.M. Whitehead, F.J. Barrett, op.cit., s. 15.

${ }^{11}$ E. Anderson, Inclusive Masculinity: The Changing Nature of Masculinities, New York 2009.

${ }^{12}$ N. Hanlon, Masculinities, Care and Equality: Identity and Nurture in Men's Lives, London 2012; K. Elliott, Caring Masculinities: Theorizing an Emerging Concept, „Men and Masculinities" 2016, vol. 19, issue 3, s. 240-259.

${ }^{13}$ The Making of Masculinities...; H. Brod, A Case for Men's Studies [w:] Changing Men: New Directions in Research on Men and Masculinity, ed. M.S. Kimmel, Newbury Park-London-New Delhi 1987, s. 263-277.

${ }^{14}$ H. Brod, A Case for Men's Studies... 
traktowanych jako istoty „,neutralne” płciowo ${ }^{15}$, ani zawłaszczenie kobiecej historii, ale raczej pokazanie, że mężczyźni wspierają kobiety, walczą o ich prawa i są profeministami.

\section{Kłopotliwa terminologia - słów kilka}

Terminologia stosowana w studiach nad mężczyznami i męskościami jest zdominowana przez język angielski. W swoim artykule Krzysztof Kłosiński ${ }^{16}$ dowodzi jednak, że studia te w języku angielskim nie mają jednolitej nomenklatury, a badaczki i badacze często w dość swobodny sposób korzystają z terminów, które wydają się kluczowe dla analizowanego obszaru. Odniosę się tu tylko do kilku wątków, gdyż Kłosiński szeroko opisuje problemy terminologiczne w swoim tekście.

W języku polskim w kontekście opisywanych studiów mówimy o mężczyznach, męskości i męskościach. Męskość jest też określeniem, które potocznie odnosi się do sfery seksualnej mężczyzny. Anglojęzyczne terminy masculinity, manhood tłumaczymy jako „męskość”, choć w wypadku tego drugiego nie występuje liczba mnoga i dlatego gdy mowa o męskościach - wprowadza się formę masculinities. W anglojęzycznej literaturze przedmiotu zwykle stosowane jest pojęcie masculinity jako jednoznacznie nieesencjalistyczne, jednak - jak zauważa Kłosiński - Michael Kimmel stosuje zarówno masculinity, jak i manhood, wykorzystuje też częściej liczbę mnogą, a w liczbie pojedynczej wprowadza crisis of masculinity (podejrzewam, że może być to związane $\mathrm{z}$ esencjalistycznym potraktowaniem kryzysu). Terminu masculinities używa on do opisu męskości w kontekście etnicznym (np. Japanese masculinities) i odmian genderowych (np. gay masculinities), z kolei sięga po liczbę pojedynczą, przedstawiając właściwości strukturalne ${ }^{17}$ (np. hegemonic masculinity), ale o męskości kobiecej pisze jak o elemencie strukturalnym, czyli female masculinity ${ }^{18}$. Z kolei Steven Whitehead wykorzystuje termin manhood

${ }_{15}$ M. Szczepaniak, ,Libido dominandi”. Męski habitus w świetle teorii socjologicznych, http://www.nowakrytyka.pl/pl/artykuly/Nk_on-line/?id=590 [dostęp: 15.09.2018].

${ }^{16}$ K. Kłosiński, De(re)konstrukcja męskości, „Teksty Drugie” 2015, nr 2, s. 12-17.

${ }^{17} \mathrm{Na}$ temat krytyki strukturalnego podejścia w studiach nad męskościami i mężczyznami zob. M. Duda, Badania nad mężczyznami w Polsce, czyli o hegemonii struktury [w:] (Nie)męskość w tekstach kultury XIX-XXI wieku, red. B. Zwolińska, K.M. Tomala, Gdańsk 2019, s. 11-22.

${ }^{18}$ Katarzyna Suwada w eseju recenzyjnym mojej książki Mężczyźni w pielęgniarstwie zwróciła uwagę na stosowanie w analizach terminu 'męskość opiekuńcza', a nie 'męskości opiekuńcze'. Singularna forma użycia tego pojęcia jest tu bowiem zaprzeczeniem wielości, która w koncepcji prezentowanej książki jest jednym z założeń. Obawiałam się nadmiernej komplikacji w zrozumieniu terminu, ale z perspektywy czasu uważam, że Suwada ma 
jako synonim boyhood, a Jeff Hearn definiuje masculinity przez użycie słów manhood i manliness, które można przetłumaczyć na język polski jako męskośśc ${ }^{19}$.

Jeszcze inną kwestią terminologiczną jest nazwa studiów: men's studies, critical studies on men and masculinities, a także male studies. W literaturoznawczych analizach najczęściej stosuje się określenie men's studies, czyli „studia męskie”. W socjologicznej perspektywie odchodzi się jednak od tego terminu, głównie ze względu na obawę przed błędnym zrozumieniem podejścia do analiz. Wyodrębniły się bowiem male studies, które również można by thumaczyć jako studia męskie, ale które opierają się na tradycyjnym wyobrażeniu męskości ${ }^{20}$. Tak więc „studia męskie” stały się zbyt pojemną kategorią. Odróżnienie perspektyw jest możliwe przez precyzyjne określenie podejścia opisanego w nazwie realizowanych studiów i dlatego profeministycznie zorientowane badaczki i badacze zaproponowali zastąpienie pojęcia zbyt ich zdaniem ogólnego terminem precyzyjniejszym. Mówiąc o „krytycznych studiach nad mężczyznami i męskościami" (critical studies on men and masculinities), chcą oni podkreślić, że subdyscyplina ta ukształtowała się „,na skutek wielu rodzajów krytyki - przede wszystkim feministycznej, ale także ze strony przedstawicieli naukowej perspektywy gejowsko-lesbijskiej, oraz jako odpowiedź samych mężczyzn, zwłaszcza mężczyzn profeministów, na feminizm i debaty dotyczące relacji genderowych" ${ }^{21}$.

\section{Socjologiczne badania nad mężczyznami i męskościami - obszary badawcze}

Przytoczona powyżej periodyzacja studiów nad mężczyznami i męskościami odnosi się jednak do specyfiki zachodnich badań. Wyłonienie się refleksji nad mężczyznami i męskościami było tam rezultatem rozwoju myśli feministycznej. Polskie refleksje nad płcią nie wpisują się w tę chronologię. Warto jednak prześledzić powstanie polskich studiów nad mężczyznami w kontekście polskiego feminizmu, który pojawia po transformacji

rację. Warto konsekwentnie pokazywać różnorodność, byśmy nie utknęli w strukturalnym pojmowaniu męskości (K. Suwada, Mężczyźni, płeć, praca opiekuńcza, „Przegląd Socjologiczny" 2017, nr 66 (2), s. 181-195).

19 Zob. K. Kłosiński, op.cit., s. 15-17.

${ }^{20}$ Zob. strona internetowa: http://www.malestudies.org [dostęp: 15.09.2018]; por. K. Wojnicka, E. Ciaputa, op.cit., s. 10-11.

${ }^{21}$ J. Hearn, From Hegemonic Masculinity to the Hegemony of Men, „Feminist Theory” 2004, vol. 5, issue 1, s. 49-72. 
polityczno-ekonomicznej ${ }^{22}$, ale związany jest ze specyficzną konstrukcją płci wytworzoną przez socjalizm. Jednym z jego głównych oficjalnych założeń była równość, a „kobiety w socjalizmie, w kontekście dostępu do rynku pracy, wykształcenia, możliwości udziału w życiu społeczno-politycznym, a także udogodnień w opiece nad dziećmi, osiągnęły status społeczny (przynajmniej formalnie) równy mężczyznom" "23. Jak sugeruje Barbara Kwaśny, ze względu na różnice w rozwoju polskiej myśli feministycznej nie doszło do rozwoju studiów nad mężczyznami i męskościami, gdyż miały one „szanse rozwinąć się tam, gdzie ruch feministyczny był na tyle znaczący, że uczynił dyskusyjnym takie pojęcia jak »płeć«, »kobiecość«, »kobieta«, »macierzyństwo«, a w konsekwencji, także takie kategorie jak »męskość«, »mężczyzna«, »ojcostwo« itd." ${ }^{24}$. Sytuacja nie zmieniła się natychmiast po roku 1989, gdyż postkomunistyczne koncepcje odbudowy państwa miały charakter patriarchalny i nacjonalistyczny, zawłaszczały kobiece ciała i nie czyniły z kobiet aktywnych podmiotów politycznych ${ }^{25}$. Zmian nie przyniosły również lata dziewięćdziesiąte, kiedy męskość nadal była traktowana jako kategoria bezproblemowa, niewymagająca refleksji.

Rozwój studiów nad mężczyznami i męskościami jest ściśle związany z profeministycznymi ruchami męskimi ${ }^{26}$. Na Zachodzie są one od dawna bardzo widoczne, w Polsce zaś pojawiły się niedawno ${ }^{27}$, są słabo rozpoznawalne społecznie, mocno zróżnicowane, słabo zorganizowane i mają niewielki wpływ na społeczne zmiany ${ }^{28}$.

Jedne $\mathrm{z}$ pierwszych polskich badań dotyczących męskości były związane $\mathrm{z}$ tematyką roli płciowej oraz różnic między kobietami i mężczyzna-

22 A. Graff, Odmienna chronologia. Refleksja nad feminizmem we współczesnej Polsce, „Zadra” 2007, nr 3-4.

${ }_{23}$ M. Baer, Pleć i procesy transformacyjne w Polsce po 1989 roku. Studium przypadku, „Rocznik Antropologii Historii” 2014, nr 2 (7), s. 291-292.

${ }^{24}$ B. Kwaśny, op.cit., s. 10.

${ }^{25}$ Ibidem, s. 11.

${ }^{26}$ Charakterystyka ruchów męskich zob. m.in.: The Politics of Manhood: Profeminist Men Respond to the Mythopoetic Men's Movement (And the Mythopoetic Leaders Answer), ed. M. S. Kimmel, Philadelphia 1995; M.A. Messner, Politics of Masculinities: Men in Movements, Lanham-Oxford 2000; M. Śmietana, Ruchy spoleczne mężczyzn na tle studiów nad męskościa [w:] Mężczyźni na rzecz zmiany, red. A. Lipowska-Teutsch, Kraków 2006, s. 5-23; U. Kluczyńska, Metamorfozy tożsamości..., s. 109-119.

${ }^{27}$ Szerzej tematykę społecznego ruchu mężczyzn w Polsce opisuje Katarzyna Wojnicka m.in. w: K. Wojnicka, J. Struzik, Mężczyźni w działaniu. Problematyka męskich ruchów społecznych w Polsce [w:] Karuzela z mężczyznami..., s. 257-278; K. Wojnicka, Męskie ruchy społeczne we wspótczesnej Polsce. Wybrane ustalenia i wnioski, „Acta Universitatis Lodziensis. Folia Sociologica" 2013, nr 47, s. 87-103.

${ }^{28}$ K. Wojnicka, J. Struzik, op.cit., s. 276. 
mi, a prowadzono je głównie w naukach psychologicznych ${ }^{29}$. Choć przed 2000 rokiem można znaleźć artykuły o męskości, to jednak przede wszystkim w pracach zbiorowych poświęconych tematyce studiów genderowych ${ }^{30}$. Teksty dotyczące analiz męskości pojawiały się przy okazji analiz kobiecości, zaś sama męskość długo nie wydawała się godnym obszarem badań ${ }^{31}$. Warto zaznaczyć, że kobiety nie tylko chętniej badają kwestie kobiecości, ale także problematyzują męskości. W polskiej refleksji socjologicznej dużo częściej to kobiety prowadzą badania w obrębie studiów nad mężczyznami i męskościami i wydaje się, że nadal mężczyźni nie do końca chcą wykorzystać możliwość podjęcia tego tematu.

Analizując tematykę społecznych studiów nad mężczyznami i męskościami, można dostrzec zbieżność w rozwoju polskich i zachodnich badań, choć w naszych realiach mamy do czynienia z opóźnieniem czasowym i sporą powtarzalnością ${ }^{32}$. Polscy badacze i badaczki przede wszystkim podejmowali temat uczenia się męskości, roli męskiej i stereotypów genderowych.

Dyskusje nad męskością w polskim piśmiennictwie otwarło popularne wówczas w anglojęzycznej literaturze założenie, że męskość jest w kryzysie. Kwestię tę przybliżył Zbyszko Melosik w książce Kryzys męskości w kulturze współczesnej ${ }^{33}$. Według autora ów kryzys związany był z zachwianiem hegemonicznej pozycji mężczyzn. Jednak zjawisko kryzysu męskości, opisywane w polskojęzycznych artykułach, nie zawsze ma negatywny wydźwięk i często jest interpretowane jako zmiana lub kryzys męskiej roli, kryzys męskości tradycyjnej ${ }^{34}$, a zatem okazja, by mówić o przemianach czy metamorfozach męskości ${ }^{35}$. W podejściu tym modyfikacjom podlegają męskości (a nie męskość) ${ }^{36}$. Niemniej Melosik odrzucał rozumienie kryzysu jako zmiany.

${ }^{29}$ M.in.: Współczesne problemy socjalizacji, red. E. Mandal, R. Stefańska-Klar, Katowice 1995; Męskość-kobiecość w perspektywie indywidualnej i kulturowej, red. J. Miluska, P. Boski, Warszawa 1999.

${ }^{30}$ M.in.: Od kobiety do mężczyzny i z powrotem. Rozważania o ptci w kulturze, red. J. Brach-Czaina, Białystok 1997; Portrety kobiet i mężczyzn w środkach masowego przekazu oraz podręcznikach szkolnych. Praca zbiorowa, red. R. Siemieńska-Żochowska, Warszawa 1997.

${ }^{31}$ Por. I. Kowalczyk, Dlaczego nie ma studiów męskich?, „Czas Kultury” 2002, nr 3, s. 33-39.

32 Wiele obszarów nadal wymaga regularnych i aktualizowanych badań, podczas gdy analiza polskich tekstów pokazuje, że badaczki i badacze podejmują często temat mężczyzn i męskości jednorazowo, na marginesie innych, głównych zainteresowań badawczych.

${ }_{33}$ Z. Melosik, Kryzys męskości w kulturze wspótczesnej, Poznań 2002.

${ }^{34}$ Por. B. Kwaśny, op.cit., s. 14.

${ }^{35}$ U. Kluczyńska, Metamorfozy tożsamości...

${ }^{36}$ Różne rozumienia kryzysu męskości opisuje m.in. K. Arcimowicz, Kryzys męskości czy szansa dla mężczyzn? Przeglad problematyki badań, „Ars Educandi” 2014, nr 11, s. 13-25. 
Tematyka kryzysu męskości do dziś powraca w analizach, choć obecnie jest podejmowana raczej przez badaczki i badaczy, które i którzy okazjonalnie analizują problematykę męskości.

Jednym z pierwszych obszarów, zresztą nadal eksplorowanych ${ }^{37}$, była kwestia męskości w kontekście mediów i kultury popularnej ${ }^{38}$. Jak podkreśla Maciej Duda, analizy te zakorzenione są przede wszystkim w strukturalnych założeniach i jako wyniki prezentują opisy typów męskości w odniesieniu do kwestii męskiej władzy ${ }^{39}$.

Innym obszarem badań było (i nadal jest) zjawisko socjalizacji, mechanizmy wtłaczające w stereotypy męskości i decydująca dla przebiegu tego procesu rola szkoły ${ }^{40}$.

Kolejnym, szczególnie interesującym polem badawczym okazał się sport jako praktyka stanowiąca istotny element konstruowania męskości. W rodzimych analizach sport i męskość łączone były głównie z dominacją i męskością hegemoniczną oraz relacjami w obrębie męskości i kobiecości, a także z rolą mediów i zjawiskiem nierówności w sporcie ${ }^{41}$.

${ }^{37} \mathrm{~Np}$. A. Majer, Dyskurs dyscyplinowania męskiego ciała $w$ wybranych tekstach kultury popularnej, Gdańsk 2016.

${ }^{38}$ K. Arcimowicz, Obraz mężczyzny...; U. Kluczyńska, Metamorfozy tożsamości...; Kobiety i mężczyźni (z) kolorowych czasopism, red. A. Łysak, E. Zierkiewicz, Wroclaw 2010; Z. Melosik, op.cit.

${ }^{39}$ M. Duda, op cit.

${ }^{40} \mathrm{~W}$ tym kontekście warto przywołać prace Lucyny Kopciewicz; zob. eadem, Podręczniki szkolne jako narzędzie przemocy symbolicznej [w:] Gender w podręcznikach, red. I. Chmura-Rutkowska et al., Warszawa 2016, t. 1, s. 81-92, http://gender-podreczniki.amu.edu.pl/ [dostęp: 15.09.2018]; eadem, Kobiecość, męskość i przemoc symboliczna. Polsko-francuskie studium porównawcze, Kraków 2005; eadem, Rodzaj i edukacja. Studium fenomenograficzne z zastosowaniem teorii społecznej Pierre'a Bourdieu, Wrocław 2007; H. Bougsiaa, L. Kopciewicz, M. Welenc, Wprowadzenie, „Ars Educandi” 2014, nr 11, s. 7-9.

${ }^{41}$ Np.: U. Kluczyńska, Sport jako obszar konstruowania tożsamości mężczyzn. Znaczenia wpisane w sport i możliwości ich redefiniowania [w:] Męskość jako kategoria kulturowa. Praktyki męskości, red. M. Dąbrowska, A. Radomski, Lublin 2010, s. 86-99; eadem, Męska dominacja i piłka nożna. Analizy medialnych prezentacji [w:] Karuzela z mężczyznami..., s. 65-89; B. Lis, Socjalizacja do normatywnej meskości. Instytucje i mechanizmy ksztaltowania heterohabitusu. Przyktady, „Ars Educandi” 2014, nr 11, s. 37-50. Analizy dotyczące tematyki sportu prowadzone przez Honoratę Jakubowską lokuję w szerszej perspektywie studiów genderowych - nie sposób jednak nie dostrzec wpływu, jaki pionierskie prace tej autorki odcisnęły na sposobie analizowania i postrzegania sportu i męskości w polskich badaniach. Zob. m.in.: Sport kobiet i mężczyzn. Uwarunkowania, granice, różnice, red. H. Jakubowska, Poznań 2013; H. Jakubowska, Gra ciałem. Praktyki i dyskursy różnicowania ptci w sporcie, Warszawa 2014; Socjologia sportu, red. H. Jakubowska, P. Nosal, Warszawa 2017. Tematyka męskości i sportu jest stosunkowo rzadko podejmowana, a jeszcze 
Kwestia przemocy i agresji mężczyzn w kontekście konstruowania męskości również została zauważona ${ }^{42}$. Jednak więcej miejsca poświęcono dotychczas problematyce ojcostwa - zarówno ojcostwa w mediach ${ }^{43}$, jak i doświadczeń ojcostwa oraz konstruowaniu roli ojca ${ }^{44}$, pytaniom o ojców nieheteroseksualnych ${ }^{45}$ czy ojców na emigracji $^{46}$.

Podjęcie tej tematyki zaowocowało dalszymi analizami męskości opiekuń$\mathrm{czych}^{47}$, a także wątku pracy emocjonalnej mężczyzn i emocji ${ }^{48}$ czy przyjaźni ${ }^{49}$.

rzadziej w kontekście niepełnosprawności. Temat ten porusza np.: J. Niedbalski, ,,Legless Aphrodite” and „Hercules in a Wheelchair" - About Disabled Women and Disabled Men Practicing Sport, „Przegląd Socjologii Jakościowej” 2016, t. 12, nr 4, s. 144-159.

${ }^{42}$ Np.: K. Wojnicka, Men, Masculinities and Physical Violence in Contemporary Europe, „Studia Humanistyczne AGH” 2015, nr 2, s. 15-31; Mężczyźni na rzecz zmiany...

${ }^{43}$ Np. K. Arcimowicz, Obraz mężczyzny...; U. Kluczyńska, Jak być „,super tata”. Kultura popularna jako obszar konstruowania roli, zadań $i$ tożsamości wspótczesnego ojca [w:] Edukacja, wychowanie, poradnictwo w kulturze popularnej, red. M. Kondracka, A. Łysak, Wrocław 2009, s. 58-75, http:/www.bibliotekacyfrowa.pl/dlibra/ docmetadata?id=27807 [dostęp: 24.03.2018]; U. Kluczyńska, Konstruowanie męskości i ojcostwa w kulturze popularnej. Analiza porad(ników) dla rodziców [w:] Poradnictwo w kulturze indywidualizmu, red. E. Zierkiewicz, V. Drabik-Podgórna, Wrocław 2010, s. 167-183.

${ }_{44}$ M.in. K. Dzwonkowska-Godula, Tradycyjnie czy nowocześnie. Wzory macierzyństwa i ojcostwa w Polsce, Łódź 2015; Nowi mężczyźni? Zmieniające się modele męskości we wspótczesnej Polsce, red. M. Fuszara, Warszawa 2008; K. Suwada, Men, Fathering and the Gender Trap. Sweden and Poland Compared, Basingstoke 2017.

${ }^{45} \mathrm{~Np}$. M. Śmietana, ,Matczyni” ojcowie? Męskość i kobiecość w hiszpańskich rodzinach ojców gejów [w:] Karuzela z mężczyznami..., s. 139-160.

${ }^{46}$ Np.: K. Suwada, ,At the End, the Father Works More and the Mother Stays Home”Polish and Swedish Fathers and (Un)achieved Work-Life Balance [w:] Balancing Work and Family in a Changing Society: The Fathers'Perspective, eds. I. Crespi, E. Ruspini, Basingstoke 2016, s. 191-205; K. Suwada, Naturalisation of the Difference: The Experience of Fatherhood in Sweden and Poland, „Studia Humanistyczne AGH” 2015, nr 2, s. 141-155; P. Pustułka, J. Struzik, M. Ślusarczyk, Caught between Breadwinning and Emotional Provisions: The Case of Polish Migrant Fathers in Norway, „Studia Humanistyczne AGH” 2015, nr 2, s. 117-139.

${ }^{47}$ Np.: Nowi mężczyźni?...; U. Kluczyńska, Older Husbands as Carers: Construction of Masculinity in Context of Care-Giving, „Studia Humanistyczne AGH” 2015, nr 2 s. 7394; eadem, „Gtupio żeby tak oddać żonę...” - konstruowanie opieki i męskości przez starych mężczyzn opiekujących się swoimi przewlekle chorymi żonami, „Autobiografia” 2016, nr 1, s. 139-159; E. Zierkiewicz, E. Mazurek, Couples Dealing with Breast Cancer: The Role of Husbands in Supporting Their Wives, „Studia Humanistyczne AGH” 2015, nr 2, s. 95-116; U. Kluczyńska, Mężczyźni w pielęgniarstwie...

${ }^{48}$ D. Galasiński, Men and the Language of Emotions, Basingstoke 2004; K. Wojnicka, E. Zierkiewicz, Emocje w ruchach społecznych na przykładzie ruchów obrony praw ojców i amazonek w Polsce, „Studia Socjologiczne” 2014, 4, s. 209-232.

${ }^{49} \mathrm{~Np}$.: B. Lis, „Męska przyjaźn’”. Kilka uwag o kondycji męsko-męskich relacji we wspótczesnej kulturze Zachodu, „InterAlia” 2015, nr 10, s. 57-72; I. Chmura-Rutkowska, J. Ostrouch, Od optymizmu do cynizmu. Studium męskiej przyjaźni [w:] Męskość w kulturze wspótczesnej, red. A. Radomski, B. Truchlińska, Lublin 2008, s. 119-130. 
Wątkami, które również są analizowane w obrębie rodzimych studiów nad mężczyznami i męskościami, jest funkcjonowanie i (re)definiowanie męskości przez mężczyzn, których - korzystając z teorii R.W. Connell - można by określić jako mężczyzn reprezentujących męskości marginalizowane. Są to starzy mężczyźni ${ }^{50}$, mężczyźni z grupy robotniczej i postrobotniczej ${ }^{51}$, migranci ${ }^{52}$, mężczyźni nieheteroseksualni ${ }^{53}$, transmężczyźni ${ }^{54}$.

Kolejnym przedmiotem refleksji w obrębie studiów nad mężczyznami i męskościami w Polsce jest ciało, które w kontekście rodzimych analiz często łączone jest $\mathrm{z}$ tematyką zdrowia mężczyzn w wymiarze fizycznym i psychofizycznym ${ }^{55}$.

${ }^{50}$ Np.: U. Kluczyńska, Czy starość ma płeć? Społeczny konstrukt mężczyzny starego $w$ świetle literatury zachodniej [w:] Dorosłość wobec starości. Oczekiwania, radości, dylematy, red. R. Konieczna-Woźniak, Poznań 2008, s. 249-260; U. Kluczyńska, Czas wolny starszych mężczyzn [w:] Ku socjologii starości. Starzenie się w biegu jednostki życia, red. J. Mucha, J. Krzyżowski, Kraków 2011, s. 83-104.

${ }^{51}$ J. Klimczak-Ziółek, Męskie ciało w dyskursie ,postrobotniczym” [w:] O współczesnych praktykach genderyzacji ciała, red. K. Wódz, J. Klimczak-Ziółek, Katowice 2014, s. 162-173; K. Wódz, J. Klimczak, Przemiany męskości. Refleksja socjologiczna z badań nad społecznościami robotniczymi [w:] Oblicza męskości / Faces of Masculinity, red. E. Bogdanowska-Jakubowska, Katowice 2017, s. 11-24; J. Klimczak-Ziółek, Przeobrażenia wzorców kobiecych i męskich w spolecznościach postrobotniczych. Refleksja z badań [w:] Zapomniane miejsca, zapomniani ludzie. Restrukturyzacja ekonomiczna a zmiana kulturowa, red. K. Wódz, Katowice 2013, s. 187-201; W. Plińska, „Górnicza tragedia” [w:] Męskość w kulturze..., s. 131-139.

${ }_{52} \mathrm{~Np} .:$ J. Bell, P. Pustułka, Multiple Masculinities of Polish Migrant Men, „NORMA” 2017, vol. 12, no. 3, s. 127-143; K. Wojnicka, P. Pustułka, Migrant Men in the Nexus of Space and (Dis)empowerment, „NORMA” 2017, vol. 12, no. 2, s. 89-95.

53 J. Kochanowski, Fantazmat zróżNICowany. Socjologiczne studium przemian tożsamości gejów, Kraków 2004; B. Lis, Gejowskie (nie)męskości. Normy ptciowe a strategie tożsamościowe gejów, Gdańsk 2015; R. Majka, Poza „,bezpieczniejszym seksem” - bareback i fetyszyzacja seksu bez zabezpieczenia, „InterAlia” 2015, nr 10, s. 195-216.

${ }^{54}$ M. Bieńkowska, Transsexual Masculinity Construction in Poland, „Studia Humanistyczne AGH” 2015, nr 2, s. 179-192; U. Kluczyńska, W. Dynarski, A.M. Kłonkowska, Poza schematem. Społeczny konstrukt ptci i seksualności, Gdańsk 2016; A.M. Kłonkowska, (Trans)mężczyźni, (trans)kobiety i seksualność. O społecznym konstruowaniu seksualności w odniesieniu do osób transptciowych, „InterAlia” 2015, nr 10, s. 121-144.

${ }_{55} \mathrm{~Np}$.: M. Frąckowiak-Sochańska, ,, Uwiktani w pteć” - od wytwarzania i reprodukowania męskości po formy przekraczania ptci. Mężczyźni w procesie psychoterapii a normatywne schematy męskości - ciagłość i zmiana, „Miscellanea Anthropologica et Sociologica” 2017, nr 2, s. 91-114; D. Galasiński, Discourses of Men's Suicide Notes: A Qualitative Analysis, London 2017; idem, Fathers, Fatherhood and Mental Illness: A Discourse Analysis of Rejection, Basingstoke 2013; idem, Men's Discourses of Depression, Basingstoke 2008; A. Majer, op.cit.; U. Kluczyńska, Męskość i zdrowie. Analiza sposobu prezentacji wybranych problemów zdrowotnych w czasopiśmie dla mężczyzn ,Men's Health” [w:] Kobiety i mężczyźni..., s. 186-203; U. Kluczyńska, Problematyka palenia papierosów i depresji 
Obszarem, który nie wyłonił się w takim stopniu jak w anglojęzycznych studiach, gdzie stanowił podstawę rozwoju studiów nad mężczyznami i męskościami, jest tematyka ruchów męskich ${ }^{56}$. Stosunkowo rzadko badane było również funkcjonowanie mężczyzn w sferze publicznej, być może dlatego, że sfera ta jest traktowana jako oczywisty obszar realizacji mężczyzn i w związku z tym nie wymaga „,dodatkowego” uzasadniania lub wyjaśniania. Można jednak wskazać na poświęcone tej problematyce analizy dotyczące polityki ${ }^{57}$ czy udziału mężczyzn w rynku pracy, choć w tym drugim wypadku bardziej interesował badaczki margines, czyli np. obecność mężczyzn w sfeminizowanych profesjach ${ }^{58}$.

Powyższe obszary analiz często wzajemnie na siebie nachodzą, np. wątek ojcostwa czy sportu często bywa analizowany pod kątem medialnych prezentacji. Występuje jednak wiele tematów zaledwie zasygnalizowanych, które jeszcze nie doczekały się pogłębionej analizy. Stosunkowo mało jest w polskiej literaturze przedmiotu rozważań teoretycznych i dyskusji dotyczących teorii, co można tłumaczyć wcześniejszym brakiem swobodnego dostępu do literatury przedmiotu. Być może stan ten spowszedniał tak bardzo, że wiele badaczek i badaczy nie dostrzega potrzeby analiz, opisu lub krytyki tych teorii.

\section{Perspektywy i teorie wykorzystywane w polskich socjologicznych studiach nad mężczyznami i męskościami}

Jakie perspektywy i które teorie są najczęściej wykorzystywane w rodzimych społecznych badaniach nad mężczyznami i męskościami, a które pomijane? Jakie motywy stoją za tymi metodologicznymi wyborami? Obecnie najczęściej przyjmowaną perspektywą polskich studiów nad mężczyznami i męskościami jest społeczny konstruktywizm. Maciej Duda uznaje, że studia te ,zakorzenione są w socjologizujących i strukturalnych założeniach. Jako wynik

w czasopiśmie dla mężczyzn „Men's Health”, „Nowiny Lekarskie” 2012, nr 5, s. 500-507; E. Zierkiewicz, Zdrowie ma płeć! Analiza problemów zdrowotnych mężczyzn w prasie kobiecej, „Nowiny Lekarskie” 2012, nr 5, s. 472-484.

${ }^{56}$ K. Wojnicka, J. Struzik, op.cit., s. 257-278; K. Wojnicka, Męskie ruchy społeczne...

${ }^{57}$ M. Dąbrowska, Obraz mężczyzny w polskim dyskursie politycznym [w:] Męskość w kulturze..., s. 109-118.

${ }^{58} \mathrm{~Np}$. Nowi mężczyźni...; U. Kluczyńska, Mężczyźni w pielęgniarstwie... Odwołuję się tu do prac, które w szerszym zakresie opisywały problematykę udziału mężczyzn w sfeminizowanych profesjach i jednoznacznie łączyły z kwestią męskości. Można bowiem przytoczyć nieliczne teksty, gdzie w ramach „ciekawostki” autorzy opisywali sytuację mężczyzn w danej profesji, np.: L. Miś, Mężczyźni a praca socjalna - analiza wybranych problemów, „Problemy Polityki Społecznej” 2014, nr 27 (4), s. 109-125; W. Kapała, P. Rucki, Mężczyźni w polskim pielęgniarstwie. Jak widza i oceniaja swój zawód polscy pielęgniarze, „Pielęgniarstwo Polskie” 2008, nr 1, s. 7-13. 
badań proponują opis grup mężczyzn lub typów męskości w kontekście męskiej władzy i opresji" ${ }^{59}$.

W początkach istnienia polskich studiów nad mężczyznami i męskościami królowały teorie, które w zachodnich badaniach były już wówczas rzadko przywoływane. To „cofnięcie się” wynikało - w moim przekonaniu z potrzeby umocowania genderowych analiz w „bezpiecznym” naukowo kontekście oraz z ograniczonego dostępu do najnowszych zachodnich prac. Podobnie jak na początku rozwoju anglojęzycznych men's studies odwoływano się w Polsce do analiz dotyczących męskiej roli: przede wszystkim do wspomnianych już czterech reguł David i Brannona ${ }^{60}$, a także w pewnym stopniu uwzględniono krytyki teorii ról płciowych ${ }^{61}$. W polskich badaniach odwoływano się również - choć często krytycznie - do Roberta Blya, którego podejście wywodziło się z założeń biologicznego esencjalizmu i według którego emancypacja kobiet stanowiła zagrożenie dla mężczyzn ${ }^{62}$. Naukowczynią, która przywoływana jest stosunkowo często - zwłaszcza w pracach sprzed lat dziesięciu - jest Elisabeth Badinter. Jej książka na temat męskiej tożsamości ${ }^{63}$ była bowiem na początkowym etapie rozwoju rodzimych studiów nad mężczyznami i męskościami jedną z nielicznych propozycji analizy męskości przetłumaczonych na język polski. Autorka przywoływana jest często w kontekście kryzysu męskości, ale również przemian modelu męskości.

W polskich studiach społecznych nad mężczyznami i męskościami (zwłaszcza w odniesieniu do problematyki szkoły, sportu) często wykorzystuje się społeczną teorię Pierre'a Bourdieu, wprowadzoną do polskiego dyskursu głównie przez jego thumaczkę i komentatorkę Lucynę Kopciewicz ${ }^{64}$.

Powszechnie stosowana jest teoria męskości hegemonicznej R.W. Connell, którą australijska badaczka przybliżyła m.in. w klasycznej już pracy Masculinities $^{65}$. Autorka podkreślała wielość męskości, w obrębie których powstaje relacja oparta na władzy i podporządkowaniu. Według tego podejścia porząadek genderowy to coś więcej niż dominacja mężczyzn nad kobietami, to także dominacja pewnych męskości nad innymi, zależna od kontekstu społeczno-kulturowego. Connell zaproponowała hierarchiczną typologię wzorców męskości właściwych dla szeroko pojmowanej kultury zachodniej. Trzonem tej strukturalnej analizy

${ }^{59}$ M. Duda, op.cit.

${ }^{60}$ The Forty-Nine Percent Majority...

${ }^{61}$ J.H. Pleck, op.cit.

${ }^{62}$ Zob. np. K. Wojnicka, Od maskulinizmu do profeminizmu. Męskie ruchy społecznezarys problematyki, ,uniGENDER” 2010, nr 1 (5), www.unigender.org/?page=biezacy\&is sue $=04 \&$ article $=04$ [dostęp: 24.03.2018].

${ }^{63}$ Zob. E. Badinter, $X Y$ - tożsamość mężczyzny, przeł. G. Przewłocki, wstęp M. Janion, Warszawa 1993.

${ }^{64}$ Zob. przede wszystkim P. Bourdieu, Męska dominacja, przeł. L. Kopciewicz, Warszawa 2004.

${ }^{65}$ R.W. Connell, op.cit. 
jest zatem przede wszystkim władza i dostęp pewnych grup mężczyzn do władzy oraz marginalizacja innych grup. Jest to teoria, która zmonopolizowała analizy męskości nie tylko w Polsce, ale także na świecie. Pojawiły się w związku z tym krytyczne głosy dotyczące braku różnorodności sposobów myślenia o mężczyznach i męskościach, a teoria Connell została poddana krytyce ${ }^{66}$.

Coraz częściej podejmowane są próby wykorzystania teorii męskości włączającej/inkluzywnej Erica Andersona ${ }^{67}$, w której męskość ukazywana jest w horyzontalnym, nie zaś hierarchicznym porządku. Autor wyróżnia dwie wersje męskości: ortodoksyjną, definiowaną w opozycji do kobiecości ${ }^{68}$, a zatem bardzo homofobiczną i mizoginistyczną ${ }^{69}$, oraz drugą - inkluzywną, będącą przeciwieństwem pierwszej. Anderson zakłada, że teoria Connell dotycząca męskości hegemonicznej jest trafna wtedy, gdy homofobia stanowi podstawę definiowania męskości hegemonicznej i można mówić o jednym dominującym typie męskości. Anderson twierdzi jednak, że skoro homofobia nie stanowi już podstawy definiowania męskości ${ }^{70}$ (gdyż mężczyźni mają coraz większą swobodę w ekspresji postaw i zachowań, które wcześniej ich stygmatyzowały) dwa wzorce męskości mogą być tak samo nagradzane społecznie. Teoria męskości inkluzywnej zakłada, że w kulturze, w której dochodzi do słabnięcia homohisterii, mogą współistnieć dwie formy męskości: tradycyjna i inkluzywna. Autor unika stosowania terminów 'męskość hegemoniczna' oraz 'inkluzywna' jako archetypów, ponieważ zakłada, że istnieje wiele męskości - zarówno ortodoksyjnych, jak i inkluzywnych ${ }^{71}$. Anderson zaznacza jednak, że jego analizy dotyczą przede wszystkim białych wykształconych mężczyzn klasy średniej ${ }^{72}$.

Wprawdzie wielu polskich badaczy sięga do poststrukturalitycznej myśli krytycznej Michela Foucault, jednak ich prace w dużym stopniu mają ciągle charakter strukturalny. Jak pisze Maciej Duda,

[...] dotychczasowe analizy polskich mężczyzn i męskości w niewielkim stopniu wykorzystywały krytyczny potencjał zawarty w postrukturalistycznych teoriach feministycznych czy teoriach i praktykach queerowych. Typizacja pozbawiona krytycznego ujęcia nosi wyraźne znamiona ujęcia niejednostkowego. Nie mówi

${ }^{66} \mathrm{~W}$ języku polskim zob.: U. Kluczyńska, Mężczyźni w pielęgniarstwie..., s. 14-19. Zob. także: R.W. Connell, J.W. Messerschmidt, Hegemonic Masculinity: Rethinking the Concept, „Gender \& Society” 2005, vol. 19, no. 6, s. 829-859.

${ }^{67}$ E. Anderson, op.cit.

${ }^{68}$ Ibidem, s. 35-36.

${ }^{69}$ Ibidem, s. 41.

${ }^{70}$ Zob. M. McCormack, The Declining Significance of Homophobia: How Teenage Boys are Redefining Masculinity and Heterosexuality, New York 2012.

${ }^{71}$ E. Anderson, op.cit., s. 31.

72 Ibidem, s. 15. 
o podmiocie, o indywidualnej tożsamości, jednostkowym doświadczeniu i autorefleksji. Te wciąga w paradygmat odpowiedniego typu lub modelu. Nie mówi też o próbach emancypacji, wyzwolenia, przemiany. Wskazuje kryzys, nie szanse ${ }^{73}$.

Myślę jednak, że istnieje szansa na zasadniczą zmianę perspektywy; pokazuje to m.in. rozwój analiz nad męskością opiekuńczą. Niemniej nadal w studiach nad męskościami i mężczyznami niewystarczająco wykorzystywany jest potencjał teorii feministycznych ${ }^{74}$. Brakuje nam namysłu nad teoretycznymi założeniami badań i krytycznej analizy teorii. Mało dyskutujemy, rzadko krytycznie myślimy o teoriach. W moim przekonaniu w polskich studiach nad mężczyznami i męskościami brakuje odpowiedników tak podstawowych krytycznych podejść i refleksji naukowych jak choćby prace C.J. Pascoe ${ }^{75}$, Tristana Bridgesa ${ }^{76}$ czy Chrisa Beasleya ${ }^{77}$.

\section{Podsumowanie - refleksja nad rozwojem społecznych studiów nad mężczyznami i męskościami w Polsce}

Zachodnie studia nad mężczyznami i męskościami mają swe korzenie w profeministycznych ruchach męskich, których polska historia jest krótsza i ma inną specyfikę, a których rozwój wiąże się między innymi z wspomnianymi powyżej czynnikami (polską ,chronologią” feminizmu, doświadczeniem socjalizmu i transformacji polityczno-ekonomicznej). Późne wyodrębnienie się studiów nad mężczyznami i męskościami w Polsce łączyło się też z dostępem - lub jego brakiem - do zachodnich/anglojęzycznych teorii i badań. W dziejach polskich badań widać szybsze przejście przez podobne stadia rozwoju, dlatego można mówić o przyspieszonym kursie z teorii i sposobu myślenia o samej dyscyplinie. Początkowa nieobecność tematyki męskości w studiach socjologicznych, a następnie niemal nieograniczony dostęp do teorii i badań zachodnich mogą albo powodować wrażenie, że ,wszystko zostało już opisane” i że ,nie mamy już czego analizować”, albo dawać poczucie doganiania Zachodu i jednoczesnej potrzeby ,,przerobienia” kolejnych kroków. $Z$ jednej strony trudno nie dostrzec marginalnej pozycji tematyki genderowej,

73 M. Duda, op.cit.

74 Zob. Ch. Beasley, Gender and Sexuality: Critical Theories, Critical Thinkers, Los Angeles etc. 2005.

75 Np.: C.J. Pascoe, Dude, You're a Fag: Masculinity and Sexuality in High School, Los Angeles-London 2007.

76 T. Bridges, C.J. Pascoe, Hybrid Masculinities: New Directions in the Sociology of Men and Masculinities, ,Sociology Compass” 2014, vol. 8, no. 3, s. 246-258.

77 Ch. Beasley, op.cit. 
a konkretnie męskiej, w polskim dyskursie akademickim, ale z drugiej wydaje się, że bardzo powoli obszar ten zaczyna uchodzić za wartościowy poznawczo. Polskie studia nad mężczyznami i męskościami powinny zmierzyć się $\mathrm{z}$ wieloma kwestiami jeszcze niepodjętymi lub zaledwie zasygnalizowanymi w nielicznych pracach. Polska socjologia męskości ma zatem jeszcze sporo do opisania i przeanalizowania.

Trafna jest wspomniana wcześniej obserwacja Barbary Kwaśny, że wczesne polskie analizy pomijają uwikłanie kategorii męskości w inne zależności (takie jak klasa, wiek, etniczność, miejsce zamieszkania, sprawność) oraz że zagubiony został kontekst transformacji ustrojowej ${ }^{78}$. Istotnie, w początkowym etapie rozwoju polskich studiów nad mężczyznami i męskościami nie została uwzględniona perspektywa intersekcjonalna, jednak z czasem badaczki i badacze dostrzegli ten brak i współczesne analizy poszerzają sposób myślenia o męskościach.

Problematyka męskości w polskich studiach socjologicznych pojawiła się znacznie później niż w myśli zachodniej i opiera(-ła) się przede wszystkim na propozycjach teoretycznych stamtąd zapożyczonych. Choć współczesne polskie badania dotyczą coraz częściej alternatywnych męskości, a badaczki i badacze najczęściej wybierają podejście konstruktywistyczne, to jednak redefinicje męskości pojawiają się jednocześnie ze studiami poświęconymi męskiej roli, dominacji, czego dowodem wydaje mi się niekończąca się popularność teorii męskości hegemonicznej R.W. Connell. Inne teorie zyskują zainteresowanie bardzo powoli. Rzadko sięga się po koncepcję męskości inkluzywnej/włączającej Andersona. Zapewne decyduje o tym kilka czynników: kontekst badawczy, w jakim teoria ta została sformułowana, czyli sport, a przede wszystkim ograniczenia jej adekwatności do społeczeństw, w których poziom homofobii nie jest kluczowy dla definiowania męskości i zarazem do mężczyzn z klasy średniej. Brakuje również polskich tekstów krytycznie analizujących teorie funkcjonujące w obrębie studiów nad mężczyznami i męskościami.

\section{Bibliografia}

Anderson E., Inclusive Masculinity: The Changing Nature of Masculinities, New York 2009.

Arcimowicz K., Kryzys męskości czy szansa dla mężczyzn? Przegląd problematyki badań, „Ars Educandi” 2014, nr 11.

Arcimowicz K., Obraz mężczyzny w polskich mediach. Prawda-fatsz - stereotyp, Gdańsk 2003.

${ }^{78}$ B. Kwaśny, op.cit., s. 16. 
Badinter E., XY-tożsamość mężczyzny, przeł. G. Przewłocki, wstęp M. Janion, Warszawa 1993.

Baer M., Płeć i procesy transformacyjne w Polsce po 1989 roku. Studium przypadku, „Rocznik Antropologii Historii” 2014, nr 2 (7).

Beasley Ch., Gender and Sexuality: Critical Theories, Critical Thinkers, Los AngelesLondon-New Delhi-Singapore-Washington 2005.

Bell J., Pustułka P., Multiple Masculinities of Polish Migrant Men, „NORMA” 2017, vol. 12 , no. 3 .

Bieńkowska M., Transsexual Masculinity Construction in Poland, „Studia Humanistyczne AGH” 2015, nr 2.

Bly R., Żelazny Jan. Rzecz o mężczyznach, przeł. J. Tittenbrun, Poznań 2004.

Bougsiaa H., Kopciewicz L., Welenc M., Wprowadzenie, „Ars Educandi” 2014, nr 11.

Bourdieu P., Meska dominacja, przeł. L. Kopciewicz, Warszawa 2004.

Bridges T., Pascoe C.J., Hybrid Masculinities: New Directions in the Sociology of Men and Masculinities, „Sociology Compass” 2014, no. 8 (3).

Brod H., A Case for Men's Studies [w:] Changing Men: New Directions in Research on Men and Masculinity, ed. M.S. Kimmel, Newbury Park-London-New Delhi 1987.

Chmura-Rutkowska I., Ostrouch J., Od optymizmu do cynizmu. Studium męskiej przyjaźni [w:] Męskość w kulturze współczesnej, red. A. Radomski, B. Truchlińska, Lublin 2008.

Connell R.W., Masculinities, Berkeley-Los Angeles 1995.

Connell R.W., Messerschmidt J.W., Hegemonic Masculinity: Rethinking the Concept, „Gender \& Society” 2005, vol. 19, no. 6.

Dąbrowska M., Obraz mężczyzny w polskim dyskursie politycznym [w:] Męskość w kulturze współczesnej, red. A. Radomski, B. Truchlińska, Lublin 2008.

Duda M., Badania nad mężczyznami w Polsce, czyli o hegemonii struktury [w:] (Nie)męskość $w$ tekstach kultury XIX-XXI wieku, red. B. Zwolińska, K.M. Tomala, Gdańsk 2019.

Dzwonkowska-Godula K., Tradycyjnie czy nowocześnie. Wzory macierzyństwa i ojcostwa w Polsce, Łódź 2015.

Elliott K., Caring Masculinities: Theorizing an Emerging Concept, „Men and Masculinities" 2016, vol. 19, issue 3.

Faludi S., Reakcja. Niewypowiedziana wojna przeciw kobietom, przeł. A. Dzierzgowska, wstęp A. Graff, Warszawa 2013.

Frąckowiak-Sochańska M., ,,Uwiktani w pteć” - od wytwarzania i reprodukowania męskości po formy przekraczania płci. Mężczyźni w procesie psychoterapii a normatywne schematy męskości - ciagłość i zmiana, „Miscellanea Anthropologica et Sociologica" 2017, $\mathrm{nr} 2$.

The Forty-Nine Percent Majority: The Male Sex Role, eds. D.S. David, R. Brannon, Reading 1976.

Galasiński D., Discourses of Men's Suicide Notes: A Qualitative Analysis, London 2017.

Galasiński D., Fathers, Fatherhood and Mental Illness: A Discourse Analysis of Rejection, Basingstoke 2013. 
Galasiński D., Men and the Language of Emotions, Basingstoke 2004.

Galasiński D., Men's Discourses of Depression, Basingstoke 2008.

Gender. Wizerunki kobiet i mężczyzn w kulturze, red. E. Durys, E. Ostrowska, Kraków 2005.

Graff A., Odmienna chronologia. Refleksja nad feminizmem we współczesnej Polsce, „Zadra” 2007, nr 3-4.

Hanlon N., Masculinities, Care and Equality: Identity and Nurture in Men's Lives, London 2012.

Hearn J., From Hegemonic Masculinity to the Hegemony of Men, „Feminist Theory” 2004, vol. 5 issue 1.

Jakubowska H., Gra ciałem. Praktyki $i$ dyskursy różnicowania płci w sporcie, Warszawa 2014.

Kapała W., Rucki P., Mężczyźni w polskim pielęgniarstwie. Jak widza i oceniają swój zawód polscy pielęgniarze, „Pielęgniarstwo Polskie” 2008, nr 1.

Klimczak-Ziółek J., Męskie ciało w dyskursie „postrobotniczym” [w:] O współczesnych praktykach genderyzacji ciała, red. K. Wódz, J. Klimczak-Ziółek, Katowice 2014.

Klimczak-Ziółek J., Przeobrażenia wzorców kobiecych i męskich w społecznościach postrobotniczych. Refleksja z badań [w:] Zapomniane miejsca, zapomniani ludzie. Restrukturyzacja ekonomiczna a zmiana kulturowa, red. K. Wódz, Katowice 2013.

Kluczyńska U., Czas wolny starszych mężczyzn [w:] Ku socjologii starości. Starzenie się w biegu jednostki życia, red. J. Mucha, J. Krzyżowski, Kraków 2011.

Kluczyńska U., Czy starość ma płeć? Społeczny konstrukt mężczyzny starego w świetle literatury zachodniej [w:] Dorosłość wobec starości. Oczekiwania, radości, dylematy, red. R. Konieczna-Woźniak, Poznań 2008.

Kluczyńska U., „, Gtupio żeby tak oddać żone...” - konstruowanie opieki i męskości przez starych mężczyzn opiekujacych się swoimi przewlekle chorymi żonami, „Autobiografia” 2016, nr 1.

Kluczyńska U., Jak być ,super tata”. Kultura popularna jako obszar konstruowania roli, zadań i tożsamości współczesnego ojca [w:] Edukacja, wychowanie, poradnictwo $w$ kulturze popularnej, red. M. Kondracka, A. Łysak, Wrocław 2009, http:// www.bibliotekacyfrowa.pl/dlibra/docmetadata?id=27807 [dostęp: 24.03.2018].

Kluczyńska U., Konstruowanie męskości i ojcostwa w kulturze popularnej. Analiza porad(ników) dla rodziców [w:] Poradnictwo w kulturze indywidualizmu, red. E. Zierkiewicz, V. Drabik-Podgórna, Wrocław 2010.

Kluczyńska U., Metamorfozy tożsamości mężczyzn w kulturze wspótczesnej, Toruń 2009. Kluczyńska U., Męska dominacja i piłka nożna. Analizy medialnych prezentacji [w:] Karuzela z mężczyznami. Problematyka męskości w polskich badaniach spotecznych, red. K. Wojnicka, E. Ciaputa, Kraków 2011.

Kluczyńska U., Męskość i zdrowie. Analiza sposobu prezentacji wybranych problemów zdrowotnych w czasopiśmie dla mężczyzn ,Men's Health” [w:] Kobiety i mężczyźni (z) kolorowych czasopism, red. A. Łysak, E. Zierkiewicz, Wrocław 2010.

Kluczyńska U., Mężczyźni w pielęgniarstwie. W stronę męskości opiekuńczej, Poznań 2017. 
Kluczyńska U., Older Husbands as Carers: Construction of Masculinity in Context of Care-Giving, „Studia Humanistyczne AGH” 2015, nr 2.

Kluczyńska U., Problematyka palenia papierosów i depresji w czasopiśmie dla mężczyzn „Men's Health”, „Nowiny Lekarskie” 2012, nr 5.

Kluczyńska U., Sport jako obszar konstruowania tożsamości mężczyzn. Znaczenia wpisane w sport i możliwości ich redefiniowania [w:] Męskość jako kategoria kulturowa. Praktyki męskości, red. M. Dąbrowska, A. Radomski, Lublin 2010.

Kluczyńska U., Dynarski W., Kłonkowska A.M., Poza schematem. Społeczny konstrukt ptci i seksualności, Gdańsk 2016.

Kluczyńska U., Wojnicka K., Wymiary męskości, „InterAlia” 2015, nr 10.

Kłonkowska A.M., (Trans)mężczyźni, (trans)kobiety i seksualność. O społecznym konstruowaniu seksualności w odniesieniu do osób transptciowych, „InterAlia” 2015, nr 10.

Kłosiński K., De(re)konstrukcja męskości, „Teksty Drugie” 2015, nr 2.

Kobiety i mężczyźni (z) kolorowych czasopism, red. A. Łysak, E. Zierkiewicz, Wrocław 2010.

Kochanowski J., Fantazmat zróżNICowany. Socjologiczne studium przemian tożsamości gejów, Kraków 2004.

Kopciewicz L., Kobiecość, męskość i przemoc symboliczna. Polsko-francuskie studium porównawcze, Kraków 2005.

Kopciewicz L., Podręczniki szkolne jako narzędzie przemocy symbolicznej [w:] Gender w podręcznikach, red. I. Chmura-Rutkowska, M. Duda, M. Mazurek, A. Sołtysiak-Łuczak, Warszawa 2016, t. 1, http://gender-podreczniki.amu.edu.pl/ [dostęp: 15.09.2018].

Kopciewicz L., Rodzaj i edukacja. Studium fenomenograficzne z zastosowaniem teorii społecznej Pierre'a Bourdieu, Wrocław 2007.

Kowalczyk I., Dlaczego nie ma studiów męskich?, „Czas Kultury” 2002, nr 3.

Kwaśny B., Polskie studia nad męskościa, „Zeszyty Etnologii Wrocławskiej” 2009, nr 1 (11).

Lis B., Gejowskie (nie)męskości. Normy ptciowe a strategie tożsamościowe gejów, Gdańsk 2015.

Lis B., ,, Męska przyjaźń”. Kilka uwag o kondycji męsko-męskich relacji we współczesnej kulturze Zachodu, „InterAlia” 2015, nr 10.

Lis B., Socjalizacja do normatywnej męskości. Instytucje i mechanizmy kształtowania heterohabitusu. Przyktady, „Ars Educandi” 2014, nr 11.

Majer A., Dyskurs dyscyplinowania męskiego ciała w wybranych tekstach kultury popularnej, Gdańsk 2016.

Majka R., Poza ,, bezpieczniejszym seksem”- bareback i fetyszyzacja seksu bez zabezpieczenia, „InterAlia” 2015, nr 10.

The Making of Masculinities: The New Men's Studies, ed. H. Brod, London-SidneyWellington 1987.

McCormack M., The Declining Significance of Homophobia: How Teenage Boys Are Redefining Masculinity and Heterosexuality, New York 2012.

Melosik Z., Kryzys męskości w kulturze wspótczesnej, Poznań 2002.

Messner M.A., Politics of Masculinities: Men in Movements, Lanham-Oxford 2000. 
Męskość-kobiecość w perspektywie indywidualnej i kulturowej, red. J. Miluska, P. Boski, Warszawa 1999.

Mężczyźni na rzecz zmiany, red. A. Lipowska-Teutsch, Kraków 2006.

Miś L., Mężczyźni a praca socjalna - analiza wybranych problemów, „Problemy Polityki Społecznej” 2014, nr 27 (4).

Niedbalski J., ,Legless Aphrodite” and ,Hercules in a Wheelchair”-About Disabled Women and Disabled Men Practicing Sport, „Przegląd Socjologii Jakościowej” 2016, t. 12, nr 4.

Nowi mężczyźni? Zmieniające się modele męskości we wspótczesnej Polsce, red. M. Fuszara, Warszawa 2008.

Od kobiety do mężczyzny i z powrotem. Rozważania o ptci w kulturze, red. J. Brach-Czaina, Białystok 1997.

Pascoe C.J., Dude, You're a Fag: Masculinity and Sexuality in High School, BerkeleyLos Angeles-London 2007.

Pleck J.H., The Myth of Masculinity, London 1981.

Plińska W., „, Górnicza tragedia” [w:] Męskość w kulturze współczesnej, red. A. Radomski, B. Truchlińska, Lublin 2008.

The Politics of Manhood: Profeminist Men Respond to the Mythopoetic Men's Movement (And the Mythopoetic Leaders Answer), ed. M.S. Kimmel, Philadelphia 1995.

Portrety kobiet i mężczyzn w środkach masowego przekazu oraz podręcznikach szkolnych. Praca zbiorowa, red. R. Siemieńska-Żochowska, Warszawa 1997.

Pustułka P., Struzik J., Ślusarczyk M., Caught between Breadwinning and Emotional Provisions: The Case of Polish Migrant Fathers in Norway, ,Studia Humanistyczne AGH" 2015, nr 2.

Socjologia sportu, red. H. Jakubowska, P. Nosal, Warszawa 2017.

Sport kobiet i mężczyzn. Uwarunkowania, granice, różnice, red. H. Jakubowska, Poznań 2013.

Suwada K., ,, At the End, the Father Works More and the Mother Stays Home”-Polish and Swedish Fathers and (Un)achieved Work-Life Balance [w:] Balancing Work and Family in a Changing Society: The Fathers'Perspective, eds. I. Crespi, E. Ruspini, Basingstoke 2016.

Suwada K., Men, Fathering and the Gender Trap: Sweden and Poland Compared, Basingstoke 2017.

Suwada K., Mężczyźni, pteć, praca opiekuńcza, „Przegląd Socjologiczny” 2017, nr 66 (2).

Suwada K., Naturalisation of the Difference: The Experience of Fatherhood in Sweden and Poland, „Studia Humanistyczne AGH” 2015, nr 2.

Szczepaniak M., ,Libido dominandi”. Męski habitus w świetle teorii socjologicznych, http://www.nowakrytyka.pl/pl/artykuly/Nk_on-line/?id=590 [dostęp: 15.09.2018].

Śmietana M., „Matczyni” ojcowie? Męskość i kobiecość w hiszpańskich rodzinach ojców gejów [w:] Karuzela z mężczyznami. Problematyka męskości w polskich badaniach spolecznych, red. K. Wojnicka, E. Ciaputa, Kraków 2011. 
Śmietana M., Ruchy społeczne mężczyzn na tle studiów nad męskościa [w:] Mężczyźni na rzecz zmiany, red. A. Lipowska-Teutsch, Kraków 2006.

Whitehead S.M., Barrett F.J., The Sociology of Masculinity [w:] The Masculinities Reader, eds. S.M. Whitehead, F.J. Barrett, Cambridge 2001.

Wojnicka K., Men, Masculinities and Physical Violence in Contemporary Europe, „Studia Humanistyczne AGH” 2015, nr 2.

Wojnicka K., Męskie ruchy społeczne we wspótczesnej Polsce: wybrane ustalenia $i$ wnioski, „Acta Universitatis Lodziensis. Folia Sociologica” 2013, nr 47.

Wojnicka K., Od maskulinizmu do profeminizmu. Męskie ruchy społeczne - zarys problematyki, ,uniGENDER” 2010, nr 1 (5), www.unigender.org/?page=biezacy \&issue $=04 \&$ article=04 [dostęp: 24.03.2018].

Wojnicka K., Ciaputa E., Wprowadzenie: refleksja naukowa nad społeczno-kulturowymi fenomenami męskości [w:] Karuzela z mężczyznami. Problematyka męskości w polskich badaniach społecznych, red. K. Wojnicka, E. Ciaputa, Kraków 2011.

Wojnicka K., Pustułka P., Migrant Men in the Nexus of Space and (Dis)empowerment, „NORMA” 2017, vol. 12, no. 2.

Wojnicka K., Struzik J., Mężczyźni w działaniu. Problematyka męskich ruchów społecznych w Polsce [w:] Karuzela z mężczyznami. Problematyka męskości w polskich badaniach społecznych, red. K. Wojnicka, E. Ciaputa, Kraków 2011.

Wojnicka K., Zierkiewicz E., Emocje w ruchach społecznych na przykładzie ruchów obrony praw ojców i amazonek w Polsce, „Studia Socjologiczne” 2014, nr 4.

Wódz K., Klimczak J., Przemiany męskości. Refleksja socjologiczna z badań nad społecznościami robotniczymi [w:] Oblicza męskości / Faces of Masculinity, red. E. Bogdanowska-Jakubowska, Katowice 2017.

Współczesne problemy socjalizacji, red. E. Mandal, R. Stefańska-Klar, Katowice 1995.

Zierkiewicz E., Zdrowie ma płeć! Analiza problemów zdrowotnych mężczyzn w prasie kobiecej, „Nowiny Lekarskie” 2012, nr 5.

Zierkiewicz E., Mazurek E., Couples Dealing with Breast Cancer: The Role of Husbands in Supporting Their Wives, ,Studia Humanistyczne AGH” 2015, nr 2. 